\title{
PENJABARAN HAK TENAGA KERJA PEREMPUAN ATAS UPAH DAN WAKTU KERJA DALAM PERATURAN PERUSAHAAN DAN PERJANJIAN KERJA
}

\author{
Oleh: \\ Diah Fitriani $^{1}$ \\ ABSTRACT
}

This study aims to identify and analyze the importance of normative Rights of workers, especially women workers. This study is an empirical law with a field study observation approach to the way to the destination research. data and data sources consist of primary legal materials, secondary law and tertiary legal materials were analyzed by using interviews with informants and respondents.

Based on the Law of the Republic of Indonesia Number 13 of 2003 on Labour, the protection of women workers to ensure the basic rights of workers, and ensure equality of opportunity and treatment without discrimination on the basis of apaun for the welfare of women workers and their families with regard to the progress the business world, the rules made in the company regulations that sesusi with the legislation in force will have an impact on the welfare of workers and the development of the company, as well as the rights and obligations of the parties between workers and the company shall set forth in writing and in detail, in order to no problems in the future.

Keywords: basic rights of women workers in conformity with human rights requirements.

\section{PENDAHULUAN \\ 1. Latar Belakang Masalah}

Permasalahan tenaga kerja banyak terjadi perkembangan di Indonesia di dalam bidang usaha. Permintaan konsumen terhadap suatu barang yang begitu banyak membuat para pemilik perusahaan meningkatkan produksinya untuk memenuhi permintaan para konsumenya. Perusahaan pun meminta kepada para pekerjanya untuk lebih meningkatkan kinerjanya terutama dalam memproduksi barang yang di pasarkan pada perusahaan tersebut. Perusahaan

MahasiswaProgram Studi Magister (S2) Ilmu Hukum Program Pascasarjana UNUD, Denpasar, Bali. Alamat : Perum Padang Lestari, Link Padang Lestari No F.5,Kerobokan Kaja,Kuta Utara, Badung, Email: diahfitriani723@yahoo.co.id kebanyakan mempekerjakan tenaga kerja perempuan dalam perusahaannya, karena pekerja perempuan dianggap lebih teliti dalam bekerja.

Secara umum ketika suatu perusahaan yang di nilai sangat berkembang pesat dalam bidang usahanya, dilihat dari perusahaan tersebutmemproduksibarangyangdipasarkan meningkat pesat. ${ }^{2}$ Memproduksi barang tersebut membutuhkan tenaga kerja yang lebih banyak agar memproduksi barang lebih cepat, tetapi pada kenyataannya perusahaan tidak mempekerjakan pekerja terlalu banyak karena mempekerjakan pekerja terlalu banyak membuat pengeluaran perusahaan

Mohammad Saleh dan Lilik Mulyadi, 2012, Seraut Wajah Pengadilan Hubungan Industrial Indonesia, PT Citra Aditya Bakti, Bandung, hlm.37. 
menjadi besar, jika mempekerjakan pekerja terlalu banyak maka upah yang dikeluarkan oleh perusahaan wajib sesuai jumlah pekerja yang bekerja. Maka dari itu perusahaan seminimal mungkin mempekerjakan pekerja pada perusahaannya.

Perusahaan pun memberikan upah terhadap pekerja tidak terlalu besar, karena pemberian upah yang terlalu besar juga akan mengakibatkan pengeluaran perusahaan menjadi besar, untuk itu perusahaan dalam merekrut pekerja perusahaan kebanyakan memilih pekerja perempuan yang tidak memiliki pendidikan tinggi dan memilih pekerja perempuan yang tidak memiliki keahlian, karena perusahaan menganggap jika pekerja perempuan tidak berpendidikan tinggi dan tidak memiliki keahlian maka pemberian upah terhadap pekerja perempuan tersebut dapat diminimalkan dan pengeluaran perusahaan menjadi kecil.

Permintaan barang yang cukup besar dan meningkat membuat para pekerja perempuan dituntut untuk bekerja secara lebih, melebihi jam kerjanya. Para pekerja perempuan pun tidak dapatberbuatapakarena mereka menganggap dirinya memiliki rasa tanggung jawab terhadap pekerjaannya. Hal tersebut membuat para pekerja perempuan bekerja lembur demi tercapainya target produksi di perusahaan tempat ia bekerja.

Begitulah perusahaan memanajemen pengeluarannya. Hal tersebut sangat merugikan para pekerja khususnya pekerja perempuan. Para pekerja perempuan yang tidak memiliki pendidikan tinggi maupun tidak memiliki keahlian khusus dalam bekerja hanya dapat pasrah atau tidak dapat berbuat apa-apa ketika dalam bekerja para pekerja perempuan wajib lembur dan mendapatkan upah yang sangat tidak sesuai dengan pekerjaan yang dilakukannya. ${ }^{3}$

Kehidupan yang cukup berat membuat perempuan bekerja demi mencukupi kebutuhan hidup di dalam keluarganya. Pekerja perempuan rela bekerja hingga larut malam karena tuntutan perusahaan yang menginginkan memproduksi barang yang banyak karena peningkatan pemesannan barang cukup meningkat. ${ }^{4}$

Perusahaan tidak mensosialisasikan atau tidak memberitahukan secara rinci mengenai hak-hak pekerja perempuan di dalam perusahaan tersebut. ${ }^{5}$ Perusahaan hanya memberitahukan mengenai aturanaturan

yang wajib ditaati oleh seluruh pekerja, maka dari itu para pekerja perempuan hanya mengetahui kewajibannya di dalam perusahaan tanpa mengetahui apa yang menjadi hak-haknya sebagai pekerja, yang ia ketahui hak nya yaitu hanya upah saja.

Hal ini sangat tidak sesuai dengan Peraturan perundangan mengenai tenaga kerja perburuhan, yang dimana UU tenaga kerja Pasal 88 ayat (3) menyebutkan bahwa hak-hak pekerja dalam mendapatkan upah meliputi $^{6}$ : upah minimum bagi pekerja; upah kerja lembur karyawan; upah tidak masuk kerja pegawai karena pekerja perempuan tersebut sedang tidak dapat bekerja; upah tidak masuk kerja karena melakukan

Abdul.R.Saliman, 2005, Hukum Bisnis Perusahaan, Kencana Prenada Media Group, Jakarta, hlm.26.

4 Adrian Sutedi, 2011, Hukum Perburuhan, Sinar Grafika, Jakarta, hlm.33.

Hermansyah, 2008, Pokok-Pokok Hukum Persaingan Usaha Di Indonesia, Kencana Prenada Media Group, Jakarta, hlm.5. 
kegiatan lain di luar pekerjaannya sesuai yang diperjanjikan; upah menjalankan hak waktu istirahatnya bagi buruh; bentukbentuk dan tata cara pembayaran upah bagi pekerja; denda yang wajib dibayarkan dan potongan upah yang wajib dilaksanakan; halhal yang dapat diperhitungkan dengan upah buruh; struktur skala pembayaran pemberian upah yang proposional; gaji untuk sebagai pembayaran pesangon; upah dan gaji untuk perhitungan pajak penghasilan buruh. ${ }^{7}$

Para pekerja perempuan dalam waktu kerja juga memiliki hak-haknya antara lain mendapat waktu cuti, waktu istirahat dan ketika pekerja perempuan bekerja hingga larut malam pun juga telah diatur dengan baik dalam undang - undang ketenagakerjaan, namun perusahaan tidak melaksanakan isi dalam undang-undang ketenagakerjaan tersebut. Hal ini juga tidak berkesesuaian dengan Pasal 27 ayat (2) UU Dasar Th 1945 yang menyebutkan setiap orang memiliki hak-hak untuk mendapatkan pekerjaan yang baik. $^{8}$

\section{Permasalahan}

Berdasarkan uraian latar belakang ini, maka terdapat 2 (dua) permasalahan yaitu :

1. Apakah hak-hak normatif tenaga kerja perempuan atas upah dan waktu kerja di dalam suatu perusahaan?

2. Bagaimanakah penjabaran hak tenaga kerja perempuan atas upah dan waktu kerja sesuai dengan persyaratan HAM di dalam Peraturan Perusahaan dan Perjanjian Kerja?

Lihat UU Ketenagakerjaan Pasal 88 ayat (3).

Aloysius Uwiyono, dkk, 2014, Asas-asas Hukum Perburuhan, PT. RajaGrafindo Persada, Jakarta, hlm.27.

8 Lihat UUD 1945 Pasal 27 ayat (2).

\section{Tujuan Penelitian}

a. Tujuan Umum

Memberikan ide-ide di dalam perkembangan ilmu pengetahuan pada bidang ilmu hukum ketenagakerjaan.

b. Tujuan Khusus

Untuk mengetahui hak-hak normatif tenaga kerja perempuan atas upah dan waktu kerja dalam suatu perusahaan, dan untuk mengetahui penjabaran hak tenaga kerja perempuan atas upah dan waktu kerja yang sesuai dengan persyaratan HAM dalam Peraturan Perusahaan dan Perjanjian Kerja.

\section{METODE PENELITIAN}

Penelitian ini menggunakan penelitian empiris. sifat penelitian menggunakan deskriptif yang memperjelaskan dengan jelas sifat masing - masing individu,keadaan kelompok-kelompok tertentu, data sumber data yang digunakan yakni data-data yang digunakan primer yang bersumber dari penelitian lapangan yaitu baik berupa dari responden maupun informan.

\section{PEMBAHASAN}

Hak-hak normatif pekerja perempuan atas upah dan waktu kerja dalam suatu perusahaan.

Pekerja perempuan memiliki hak mendapatkan upah minimum, mendapatkan upah kerja lembur ketika dalam bekerja melebihi waktu yang ditentukan maka jam kerja tersebut termasuk jam kerja lembur, mendapat upah ketika pekerja ijin kerja, mendapatkan upah berhalangan kerja ketika pekerja perempuan melakukan kegiatan lain atau tugas lain yang diberikan perusahaan di luar pekerjaan yang telah disepakati, 
mendapatkan gaji yang sedang menunaikan jam istirahat, waktu itirahat sangat penting karena mengingat pekerja perempuan memiliki fisik yang berbeda dengan pekerja laki-laki, mendapatkan pembayaran pesangon, upah untuk penghitungan pajak penghasilan. ${ }^{9}$

Hak normatif mengenai waktu kerja, Pasal 76 UU tenaga kerja menyebutkan antara jam sebelas malam sampai dengan jam tujuh pagi wanita yang berumur kurang dari 18 Th dilarang bekerja karena akan membahayakan kesehatan serta keselamatan fungsi reproduksinya. Apabila ada perusahaan yang mempekerjakan perempuan antara pukul dua puluh tiga petang sampai dengan jam tujuh pagi maka perusahaan berkewajiban memenuhi makan serta minum yang sehat serta perusahaan wajib mejamin keselamatan pekerja perempuan pada saat bekerja pada malam hari dengan waktu yang telah ditentukan, dan perusahaan wajib pula menyediakan angkutan antar jemput bagi pekerja perempuannya yang pulang bekerja antara pukul sebelas petang malam sampai dengan pukul lima pagi. ${ }^{10}$

Perusahaan wajib memberikan waktu istirahat, yang dimana waktu istirahat sangat penting bagi pekerja karena istirahat dapat mengembalikan kesegaran para pekerja perempuan yang lelah melakukan kegiatan dalam bekerja, waktu istirahat juga dapat menghilangkan kejenuhan saat bekerja. ${ }^{11}$

Imam Sjahputra, 2013, Hukum Ketenagakerjaan, Harvarindo, Jakarta, hlm.29.

10 Purwanto, dkk, 2005, Hukum Perburuhan Bidang Kesehatan dan Keselamatan Kerja, Badan Penerbit Fakultas Hukum Unibversitas Indonesia, Jakarta, hlm.29.

11 Asri Wijayanti, 2009, Hukum Ketenagakerjaan Pasca Reformasi, Sinar Grafika, Jakarta, hlm.34.
Adapun waktu istirahat dan waktu cuti lainnya antara lain istirahat antara waktu kerja, istirahat mingguan, cuti tahunan, istirahat panjang,cuti haid,cuti hamil,cuti keguguran kandungan.

Mempekerjakan perempuan dalam perusahaan tidaklah mudah karena secara fisik sangat berbeda dengan laki-laki, yang lebih utama kesusilaan pekerja perempuan wajib dijaga terutama saat bekerja pada malam hari. ${ }^{12}$ Pada umumnya waktu kerja yang dilaksanakan dalam praktik adalah 7/jam perhari atau 42 /jam per minggu atau 6 hari kerja dalam satu minggu atau delapan jam per hari atau empat puluh jam per minggu untuk delapan hari kerja dalam satu minggu. ${ }^{13}$ UU HAM Nomor 39 Th 1999 juga menyebutkan perempuan dalam bekerja memiliki kesempatan untuk memilih maupun dipilih serta diangkat dalam pekerjaannya maupun dalam jabatannya berkesesuaian peraturan dan persyaratan perempuan juga dilindungi yang sangat baik untuk kegiatan pekerjaannya terhadap hal-hal yang dapat mengancam kesehatan serta keselamatan yang mempengaruhi reproduksinya, adapun sangat dekat dalam perempuan dikarenakan reproduksi perempuan sangat diperhatikan serta mendapat perlindungan hukum pada negara. ${ }^{14}$

Perusahaan membuat peraturan minimal memuat hak dan keharusan para pihak antara pekerja dan pengusaha,

Ahmadi Miru, 2010, Hukum Kontrak Perancangan Kontrak, PT RajaGrafindo Persada, Jakarta, hlm.145.

13 Zaeni Asyhadie, 2007, Hukum Kerja Ketenagakerjaan Bidang Hubungan Kerja, PT. RajaGrafindo, Persada, Jakarta, hlm.5.

14 Lihat Undang-undang HAM Pasal 49 ayat (1), (2), (3). 
memuat syarat-syarat kerja, memuat aturan perusahaan yang wajib ditaati untuk para pihak serta jangka waktu berlakunya peraturan perusahaan ini telah diatur dalam Pasal 111 ayat (1) UU Keterjaan. ${ }^{15}$ Masa berlakunya suatu peraturan tersebut paling lama 2 (dua) th dan harus diperbaharui setelah selesai jangka berlakunya peraturan tersebut. ${ }^{16}$ Jika aturan perusahaan telah dibuat sesuai dengan perundangan maka Peraturan Perusahaan tersebut dapat dikatakan telah memenuhi persyaratan HAM. ${ }^{17}$

Perjanjian Kerja dibuat apabila adanya hubungan kerja, adapun beberapa unsur hubungan kerja yang dimaksud yakni :18 adanya unsur work atau pekerjaan, adanya unsur perintah (command), adanya upah (pay). Perjanjian kerja wajib memenuhi syarat-syarat sah nya perjanjian sebagaimana telah diatur dalam Pasal 1320 KUHPerdata yang menyebutkan bahwa perjanjian dibuat adanya kesepakatan yang telah mengikatkan dirinya, para pihak yang membuat perjanjian wajib cakap dalam hukum, perjanjian dibuat karena suatu hal tertentu, dank arena adanya suatu sebab yang halal. Pasal 52 ayat (1) UU tenagakerja menngatakan sah nya perikatan apabila kedua belah pihak telah sepakat, adanya kecakapan hukum dalam bertindak mengenai perbuatan hukum, adanya jenis pekerjaan yang sesuai telah disepakati,

15 Lihat Undang-undang Ketenagakerjaan Pasal 111 ayat (1).

16 Sylvia Dwi Iswari, 2014, Apa Hak Kamu Sebagai Karyawan Kontrak, Membuka Tabir Hak dan Kewajiban Karyawan Dalam Perusahan, Lembar Langit Indonesia, Jawa Barat, hlm.7.

17 Eddie Sius Riyadi, 2008, Hak Asasi Manusia, ELSAM, Jakarta, hlm.6.

18 Lalu Husni, 2014, Pengantar Hukum Ketenagakerjaan, PT RajaGrafindo Persada, Jakarta, hlm.142. pekerjaan tidak boleh melanggar peraturan secara umum, dan ketentuan perundangan lainnya. ${ }^{19}$

Kesepakatan kerja tertuang nama lengap sesuai KTP ,alamat kediaman dan bentuk usaha pada perusahaan, nama terang, jenis kelamin dan alamat tempat tinggal buruh, jabatan dan jenis pekerjaan, tempat pekerjaan, upah yang diterima pekerja beserta cara pembayaran upahnya, wajib berisikan persyaratan kerja yang memuat hak dan kewajiban buruh dan majikan, mulai masa waktu berlakunya perikatan kerja yang telah dibuat, berisikan tanggal dan tempat dimana perjanjian kerja tersebut dibuat, serta tak lupa berisikan tanda tangan para pihak antara peketja dengan pengusaha. ${ }^{20}$

Pembuatan perjanjian kerja tidak membolehkan adanya masa percobaan dalam perjanjian kerja untuk waktu tertentu karena perjanjian kerja relatif sangat singkat, dalam keadaan percobaan pengusaha tidak diperbolehkan memberikan uang lebih rendah dari UM (upah minimum) yang ada diatur dalam aturan perundangan yang berlaku. $^{21}$

Pasal 59 pada ayat (1) undang-undang tenagakerja bahwa perikatan kerja untuk jangka waktu tertentu dibuat untuk masa waktu tertentu juga ,yang dimaksud dengan pasal 59 di atas yaitu perjanjian yang hanya sekali dan bersifat sementara,pekerjaan yang

Arief Kusuma, Perlindungan Tenaga Kerja http:/ jurnal.hukum.uns.ac.id/index.php/YTustisia/article/ viewfile/335/313, di akses 30 Agustus 2014.

20 Dewi, 2011, Keadilan Bagi Buruh, http://www. academia.edu/5634699, di akses 29 Agustus 2014.

21 Agusmidah, 2010, Dinamika dan Kajian Teori Hukum Ketenagakerjaan Indonesia, Ghalia Indonesia, Bogor, hlm.33. 
dapat digambarkan selesai dengan waktu tempo yang singkat dan selesai dalam jangka tiga (3) th, pekerjaan yang memiliki sifat hanya musiman, sifat kerja yang memiliki hubungan dengan produksi terbaru, memiliki kegiatan atas jenis produk tambahan yang baru dalam percobaan. ${ }^{22}$

Kewajiban-kewajiban para pihak yang tertulis dalam perjanjian kerja Pasal 1603, 1603 a, 1603 b, dan 1603 c KUHPerdata menyebutkan bahwa pekerja wajib melakukan pekerjaannya sendiri dan mandiri meskipun dengan seijin pengusaha dapat diwakilkan, pekerja berkewajiban mentaati aturan dan petunjuk perusahaan dalam melakukan kegiatan pekerjaannya, apabila pekerja melakukan hal yang merugikan perusahaan maka pekerja wajib membayar ganti rugi atau denda. ${ }^{23}$

Kewajiban pengusaha membayar upah terhadap pekerja yang telah melaksanakan kewajibanya dalam bekerja, wajib memberikan cuti terhadap pekerja, mengurus perawatan dan pengobatan pekerja yang pekerja bertempat tinggal satu rumah dengan majikannya, dan pengusaha wajib membuat surat keterangan yang dibubuhi tanda tangan pengusaha yang dalam surat keterangan berisikan sifat pekerjaan yang harus dilakukan pekerja, lamanya pekerja harus bekerja,surat keterangan juga diberikan meskipun inisiatif ada pemutusan hubungan kerja yang datangnya dari pihak ketiga, karena hal tersebut sangat penting sebagai

22 Artadi dan Rai Asmara Putra, 2014, Implementasi Ketentuan-ketentuan Hukum Perjanjian Ke Dalam Perancangan Kontrak, Udayana University Press, Denpasar, hlm.57.

23 Payaman Simanjuntak, 2009, Manajemen Hubungan Industrial, Jala Permata Aksara, Jakarta, hlm.36. bekal pekerja jika suatu saat nanti pekerja tersebut mencari pekerjaan yang baru yang sesuai dengan pengalamannya. ${ }^{24}$

\section{PENUTUP}

\section{Kesimpulan}

Adapun simpulan yang dapat di tarik yakni sebagai berikut:

1) Perusahaan memiliki peraturan perusahaan masing-masing,peraturan tersubut dibuat sepihak oleh perusahaan. Peraturan perusahaan wajib ditaati oleh seluruh pekerja, apabila pembuatan peraturan perusahaan tersebut berkesesuaian dengan aturan perundangan yang ada, maka aturan perusahaan tersebut telah memenuhi persyaratan HAM.

2) Subyek kerja dalam hubungan kerja pada hakikatnya merupakan inti dari perikatankerja, danyangmenjadiobyek dalam kesepakatan kerja yakni tenaga kerja yang telah melekat pada pekerja perempuan, atas dasar dari tenaga yang telah dikeluarkan oleh pekerja maka pekerja berhak mendapatkan upah yang telah diperjanjikan dalam aturan kesepakatan kerja. ${ }^{25}$ Kewajiban serta hak-hak para pihak wajib tertulis secara rinci untuk perikatan kerja dan tidak bisa melanggar dengan peraturan perburuhan Apabila dalam pembuatan perjanjian kerja telah sesuai dengan

24 Nurul Qamar, 2013, Hak Asasi Manusia Dalam Negara Hukum Demokrasi (Human Rights in Democratiche Rechtsstaat), Sinar Grafika, Jakarta, hlm. 87.

25 Adisu Edytus, 2008, Hak-hak Para Karyawan Atas Gaji, Upah dan Pedoman dalam Menghitung, Lembar Langit IOndonesia, Jawa Barat, hlm.46. 
undang-undang yang berlaku maka memenuhi persyaratan HAM.

\section{Saran}

Dari pembahasan ini adapun saran-saran yang bisa dapat diberikan dalam tulisan ini: 1). Saran untuk pihak perusahaan

Meskipun perjanjian dibuat secara sepihak oleh perusahaan yang telah berbentuk perjanjian baku, agar tidak melupakan asas kebebasan berkontrak setidak-tidaknya pihak pekerja dapat diberikan kesempatan untuk mengajukan keinginann dan aspirasinya. peraturan perusaan dan perjanjian kerja sebaiknya dibuat dengan jelas apa yang menjadi hak dan kewajiban pekerja dan apa yang menjadi hak dan kewajiban perusahaan sertaperusahaansebaiknyamensosialisasikan kepada pekerja perempuan mengenai hakhak apa saja yang wajib diperoleh saat pekerja perempuan bekerja mengingat secara fisik berbeda dengan pekerja laki-laki, serta fungsi reproduksi yang sangat dilindungi oleh hukum.

2). Saran untuk pihak Dinas Tenaga Kerja

Diharapkan lebih merespon serta lebih mengambil tindakan terhadap perusahaan yang mempekerjakan pekerja perempuan yang tidak sesuai dengan peraturan perburuhan yang berlaku agar UU Tenagakerja dan perundangan lainnya yang khususnya berkaitan dengan pemberian upah dan waktu kerja terhadap pekerja perempuan dapat diimplementasikan dengan baik di masyarakat. Dan diharapkan pula dapat memberikan perlindungan-perlindungan dalam hukum khususnya terhadap karyawan perempuan dapat dengan melalui pendaftaran Peraturan dalam perusahaan dan Perjanjian. Bagi Dinas Krjaan serta mensosialisasikan mengenai aturan perundangan dalam bidang perburuhan dan adanya pemeriksaan pada seluruh perkantoran danlebih menegakkan sanksi untuk perusahan yang telah dengan keras melanggar peraturan perundangundangan.

\section{DAFTAR PUSTAKA}

\section{Buku :}

Agusmidah,2010, cetakan pertama Dinamika serta Kajian Hukum Tenagakerjaan Indonesia, Penerbit GhaliaIndonesia, Bogor.

Artadi dan Asmara Rai Putra, 2014, Implementasi Ketentuan Hukum Perjanjian Ke Dalam Kontrak, Udayana Press University, Denpasar Bali.

Asyhadie Zaeni, 2007, Hukum Kerja Ketenagakerjaan Bidang Hubungan Kerja, PT Raja Grafindo Persada, Jakarta.

Dwi Iswari Sylvia, 2014, Apa Hak Kamu Sebagai Karyawan Kontrak Membuka Tabir Hak Dan Kewajiban Karyawan Dalam Perusahan, Lembar Langit Indonesia, Jawa Barat.

Edytus Adisu, 2008, cetakan ke-1 Hak Bagi Karyawan Atas Gaji Dan Pedoman Menghitung, Lembar Langit, Jawa Barat

Hermansyah, 2008, Pokok-Pokok Hukum Persaingan Usaha Di Indonesia, Kencana Prenada Media Group, Jakarta..

Husni Lalu, 2014, Pengantar Hukum Ketenagakerjaan, PT RajaGrafindo Persada, Jakarta. 
Miru Ahmadi, 2010, Hukum Perikatan Untuk Kontrak Perancangan Kontrak, PT RajaGrafindo, Jkt.

Purwanto, dkk, 2005, Hukum Perburuhan Bidang Kesehatan Dan Keselamatan Kerja, Badan Penerbit Fakultas Hukum Universitas Indonesia, Jakarta.

Qamar Nurul, 2013, Hak Asasi Manusia Dalam Negara Hukum Demokrasi Sinar Garfika, Jakarta.

Riyadi Eddie, 2008, Hak Asasi Manusia, ELSAM, Jakarta.

Saleh Mohammad, dan Mulyadi Lilik, 2012, Seraut Wajah Pengadilan Hubungan Indusdtrial Indonesia, PT Citra Aditya Bakti, Jakarta.

Saliman.R.Abdul, 2005, Hukum Bisnis

Untuk Perusahaan, Prenada Media Group, Jakarta.

Simanjuntak.J.Payaman, 2009, Manajemen Hubungan Industrial, Jala Permata Aksara, Jakarta.

Sjahputra Imam, 2013, Hukum Ketenagakerjaan, Harvarindo,Jakarta. Sutedi Adrian, 2011, Hukum Perburuhan, Sinar Grafika, Jakarta.

Uwiyono Aloysius, dkk, 2014, Asas-asas Hukum Perburuhan, PT. RajaGrafindo Persada, Jakarta.

Wijayanti Asri, 2009, Hukum

Ketenagakerjaan Pasca Reformasi, Sinar Grafika, Jakarta.

Internet :

Dewi, 2011, Keadilan Bagi Buruh, tersedia di http://www.academia.edu/5634699, di akses 30 Agustus 2014.

Konvensi No. 100/1951 ILO tentang Pemberian Upah Yang Sama Nilainya
Bagi Pekerja Pria Dan Perempuan, Di ia di akses 25 Desember 2014.

\section{Jurnal :}

Kusuma Arief, 2011, Perlindungan Tenaga Kerja, tersedia di http://Jurnal.Hukum. uns.ac.id/in 